\title{
PENGARUH DUKUNGAN SOSIAL TERHADAP PERTUMBUHAN PASCA TRAUMA PADA KORBAN DIFABEL AKIBAT BENCANA GEMPA
}

\author{
Yudi Tri Harsono ${ }^{1}$, Femmi Nurmalitasari ${ }^{2}$, \& Sofia Retnowati ${ }^{2}$ \\ ${ }^{1}$ Fakultas Psikologi, Universitas Negeri Malang, Jl. Semarang 5,Malang 65145, Indonesia \\ ${ }^{2}$ Fakultas Psikologi, Universitas Gadjah Mada, Bulaksumur, Yogyakarta 55281, Indonesia
}

Korespondensi: yudi.tri.fppsi@um.ac.id

\section{THE ROLE OF SOCIAL SUPPORT IN PROMOTING POST TRAUMATIC GROWTH OF NATURAL DISASTER SURVIVORS WITH PERMANENT DISABILITY}

\begin{abstract}
The earthquake occurring in Yogyakarta in 2006 left long term consequences, especially to those who experienced disability as a result of the disaster. Post traumatic growth is an individual's positive interpretation of negative experiences or feelings as result of his struggles in overcoming life challenges. This research aims to explore the role of social support in post traumatic growth on diffable survivors of Yogyakarta earthquake. The subjects were survivors of Yogyakarta earthquake in $2006(N=51)$ who suffered upper and lower limbs disability in arms, feet, and spinal cord. Data were collected using Post Traumatic Growth Scale and Sosial Support Scale. The multiple regression analysis suggested that social support significantly contributed to posttraumatic growth among survivors with disabilities of the Yogyakarta earthquake.
\end{abstract}

Manuscript type: Original Research

\section{Article history:}

Received 9 April 2019

Received in revised form 17 April 2019

Accepted 8 September 2020

Available online 14 September 2020

\section{Keywords}

disabilities

natural disaster

posttraumatic growth

social support

\begin{abstract}
Abstrak
Bencana gempa di Yogyakarta tahun 2006 masih menyisakan banyak permasalahan, terutama bagi mereka yang mengalami difabel akibat gempa. Pertumbuhan pasca trauma merupakan pemaknaan positif dari pengalaman atau perasaan negatif yang terjadi pada individu sebagai hasil dari perjuangan melawan kehidupan yang menantang. Tujuan penelitian ini adalah untuk mengetahui peran dukungan sosial terhadap pertumbuhan pasca trauma pada difabel akibat gempa. Subjek penelitian merupakan korban gempa bumi Yogyakarta tahun $2006(N=51)$ yang mengalami disabilitias fisik pada anggota gerak, seperti tangan, kaki, dan tulang belakang. Pengumpulan data dilakukan dengan menggunakan Skala Pertumbuhan Pasca Trauma dan Skala Dukungan Sosial. Hasil analisis regresi penelitian ini menunjukkan bahwa dukungan sosial berkontribusi positif terhadap pertumbuhan pasca trauma pada difabel akibat gempa.
\end{abstract}

Kata Kunci: akibat gempa, difabel, dukungan sosial, pertumbuhan pasca trauma

Dampak dan Implikasi dalam Konteks Ulayat

Terletak di garis khatulistiwa, Indonesia rentan mengalami bencana alam, sehingga studi terhadap pemulihan pada korban bencana alam penting dilakukan. Studi ini menunjukkan bahwa dukungan sosial dari komunitas di luar keluarga berkontribusi lebih besar terhadap pertumbuhan pasca trauma daripada yang bersumber dari keluarga. Hasil ini secara implisit menunjukkan internalisasi nilai gotong-royong yang merupakan praktik ulayat, yang diperkenalkan melalui adat Jawa. Nilai yang mengandung saling keterkaitan antar manusia dalam masyarakat, mendorong untuk memelihara hubungan baik serta saling menyesuaikan diri dalam kebersamaan dengan perasaan sama tinggi sama rendah. 


\section{PENDAHULUAN}

Indonesia memiliki potensi bencana yang sangat tinggi dan terjadi merata di seluruh wilayahnya. Provinsi Daerah Istimewa Yogyakarta (DIY) menjadi salah satu wilayah rawan bencana di Pulau Jawa, terutama Kabupaten Bantul. Ditinjau dari kondisi geografisnya, letak Kabupaten Bantul berada di zona subduksi lempeng Australia dan Eurasia yang merupakan wilayah rawan gempa dan tsunami (Grehenson, 2011).

Berdasarkan laporan data jumlah korban gempa DIY-Jateng, jumlah korban selamat akibat gempa sebanyak 169,000 orang yang mayoritas mengalami luka berat, di antaranya kecacatan (Sofyan, 2010). Undang-Undang Republik Indonesia Nomor 4 Tahun 1997 mendefinisikan penyandang cacat sebagai setiap orang yang mempunyai kelainan fisik dan/atau mental, yang dapat mengganggu atau merupakan rintangan dan hambatan baginya untuk melakukan secara selayaknya. Penyandang cacat dibagi dalam tiga kategori yang terdiri dari: 1). penyandang cacat fisik; 2). penyandang cacat mental; dan 3). penyandang cacat fisik dan mental. Istilah yang digunakan untuk penyandang cacat atau penyandang disabilitas telah diubah menjadi difabel.

Berdasarkan observasi di lapangan, peneliti menemukan bahwa difabel fisik yang saat ini masih dialami para korban gempa, yaitu pada bagian kaki, tangan, dan tulang belakang. Difabel pada tulang belakang menjadi yang paling banyak ditemukan. Difabel fisik pada anggota gerak mengakibatkan para korban gempa mengalami kesulitan dalam menjalani aktivitas sehari-hari, sehingga menjadi sangat tergantung kepada orang lain.

Hingga saat ini, para korban gempa masih mengalami berbagai permasalahan, seperti penerimaan terhadap diri yang baru (pasca gempa) dan penerimaan lingkungan. Djati (2010) menyatakan bahwa survei yang dilakukan oleh Sentra Advokasi Perempuan Difabel dan Anak (SAPDA) pada kelompok perempuan difabel korban gempa di wilayah Bantul, yaitu Kecamatan Jetis dan Bambanglipuro berkaitan dengan pembangunan motivasi dan penerimaan diri, melaporkan sebanyak 50 responden (60\%) perempuan difabel korban gempa masih belum menerima bahwa dirinya menjadi difabel. Rata-rata responden masih malu untuk keluar rumah, merasa rendah diri, sedih dengan kondisi yang dialami, dukungan keluarga yang masih kurang, serta masih belum memiliki keberanian untuk mengeluarkan dan menyampaikan pendapatnya (Djati, 2010). Hal ini tentu saja berdampak langsung pada status sosial, ekonomi, dan psikologis para korban gempa yang menimbulkan trauma tersendiri. 
Dalam kriteria diagnostik DSM-IV-TR (American Psychiatric Association, 2000), trauma hanya dapat dirasakan oleh mereka yang mengalami, menyaksikan, atau menghadapi kejadiankejadian berupa ancaman kematian atau kematian yang sesungguhnya, cedera serius, atau ancaman terhadap integritas fisik diri sendiri maupun orang lain. Hal ini disertai dengan respos berupa ketakutan yang hebat, rasa tidak berdaya, atau horor.

Bensimon (2012) menemukan dua respons individu saat menghadapi peristiwa traumatis, yaitu respons negatif dan positif. Bentuk respons negatif digambarkan dengan stres dan depresi yang disebut dengan istilah posttraumatic stress disorder (PTSD). Sementara itu, bentuk respon positif pasca trauma disebut dengan resiliensi dan baru-baru ini dikenal dengan istilah posttraumatic growth (pertumbuhan pasca trauma) (Tedeschi \& Calhoun, 1996; 2004).

Penelitian tentang pertumbuhan pasca trauma pada korban gempa telah dilakukan oleh beberapa peneliti baru baru ini (He, Xu, \& Wu, 2013; Tang, 2006; Urbayatun, 2012; Xu \& Liao, 2011; Yu dkk., 2010) dan ditemukan bahwa salah satu prediktor terbaik pertumbuhan pasca trauma adalah dukungan sosial (Linley \& Joseph, 2004; Sawyer, Ayers, \& Field, 2010).

Cohen dan Wills (1985) menemukan bahwa dukungan sosial dapat membantu individu dalam mengevaluasi peristiwa untuk mengurangi stres dan telah terbukti mampu memengaruhi kesehatan. Dukungan sosial dapat memengaruhi peristiwa traumatis dengan beberapa cara, yaitu membiarkan individu yang mengalami trauma untuk berbicara mengenai pengalaman yang mereka rasakan, sehingga membuat individu memiliki kesempatan untuk menerima dukungan emotional maupun umpan balik informasi mengenai peristiwa stres yang dihadapinya (Swickert \& Hittner, 2009).

Oleh karena itu, penelitian ini ingin mengetahui peran dukungan sosial terhadap pertumbuhan pasca trauma pada korban bencana gempa yang mengalami difabel.

\section{METODE}

\section{Partisipan}

Partisipan dalam penelitian ini adalah korban gempa bumi yang mengalami difabel pasca terjadi gempa bumi tahun 2006 di wilayah Bantul, khususnya pada anggota gerak, seperti tangan, kaki, atau saraf tulang belakang, berada dalam rentang usia dewasa muda ( $\geq 20$ tahun), serta bersedia menjadi subjek penelitian. 


\section{Desain}

Penelitian ini menggunakan penelitian kuantitatif untuk memperoleh data dalam bentuk kuantifikasi, yaitu bentuk angka (Sugiyono, 2012). Rancangan penelitian yang digunakan adalah regresi linier sederhana, yaitu suatu penelitian yang memprediksi hubungan satu variabel dependen dengan satu atau lebih variabel independen (Priyatno, 2013). Variabel dalam penelitian ini adalah pertumbuhan pasca trauma sebagai variabel dependen dan dukungan sosial sebagai variabel independen.

\section{Prosedur}

Tahap persiapan dalam penelitian ini diawali dengan mencari topik permasalahan yang menarik dan dikembangkan dengan menyusun latar belakang, serta melakukan tinjauan pustaka sesuai dengan topik permasalahan yang akan diteliti. Kemudian, peneliti merancang dan mengembangkan alat ukur yang digunakan. Penelitian ini menggunakan skala sebagai metode pengumpulan data, yaitu skala pertumbuhan pasca trauma dan skala dukungan sosial. Skala merupakan perangkat pernyataan yang disusun untuk mengungkap atribut tertentu melalui respons terhadap pertanyaan (Azwar, 2014).

Skala pertumbuhan pasca trauma yang digunakan dalam penelitian ini disusun berdasarkan teori pertumbuhan pasca trauma oleh Tedeschi dan Calhoun (1996) yang telah dimodifikasi oleh Urbayatun (2012). Skala ini terdiri dari lima aspek, yaitu: 1). peningkatan hubungan dengan orang lain; 2). identifikasi kemungkinan atau peluang baru; 3). meningkatnya kekuatan personal; 4). perubahan spiritual yang positif; dan 5). peningkatan dalam mengapresiasi hidup.

Skala dukungan sosial dalam penelitian ini menggunakan skala dukungan sosial yang telah dikembangkan oleh Urbayatun (2012) yang terdiri dari tiga bentuk, yaitu dukungan afeksi, dukungan sarana, dan dukungan aktivitas. Skala ini terdiri dari 14 butir. Selanjutnya, peneliti menambahkan sumber dukungan sosial yang dibagi menjadi dua, yaitu yang bersumber dari keluarga (pasangan, suami, istri, anak, anggota keluarga lainnya, kerabat/saudara) dan yang bersumber dari luar keluarga atau non-keluarga (teman, sahabat, tetangga, masyarakat/komunitas, pemerintah). Oleh karena itu, jumlah butir yang digunakan dalam skala dukungan sosial bertambah menjadi 24 butir yang terdiri dari butir favorabel dan unfavorabel.

Pada tahap pelaksanaan, peneliti menyebarkan alat ukur kepada partisipan yang memenuhi kriteria. Penelitian ini menggunakan data uji coba terpakai karena terbatasnya jumlah partisipan. 


\section{Teknik Analisis}

Analisis data menggunakan teknik analisis regresi sederhana. Sebelum uji coba hipotesis, diadakan uji asumsi yang terdiri dari uji normalitas, uji linearitas, uji multikolinieritas, uji autokorelasi, dan uji heteroskedastisitas sebagai prasyarat analisis regresi. Data yang diperoleh dalam penelitian ini dianalisis dengan menggunakan program SPSS 16.0 for Window.

\section{ANALISIS DAN HASIL}

Penelitian dilakukan di Kabupaten Bantul dengan mendatangi rumah subjek satu per satu melalui data awal yang diperoleh dari Balai Rehabilitasi Terpadu Penyandang Disabilitas Provinsi DIY. Sumber data juga diperoleh dari lembaga masyarakat Paguyuban Penyandang Paraplegia Yogyakarta (P3Y) di Stadion Sultan Agung Bantul sebagai tempat latihan mingguan olahraga tenis yang dinaungi Komite Olahraga Nasional Indonesia (KONI) dan subjek penelitian yang sudah didatangi. Tabel 1 merangkum deskripsi subjek penelitian.

Tabel 1.

Deskripsi Subjek Penelitian

\begin{tabular}{lcc}
\hline \multicolumn{1}{c}{ Deskripsi Subjek } & Frekuensi & Persentase \\
\hline Jenis Kelamin & 20 & $39.22 \%$ \\
Pria & 31 & $60.78 \%$ \\
Wanita & & \\
Usia & 19 & $37.25 \%$ \\
Masa awal dewasa (20-35 tahun) & 32 & $62.75 \%$ \\
Masa pertengahan dewasa (36-60 tahun) & & \\
Pendidikan & & \\
SD & 22 & $43.14 \%$ \\
SMP & 8 & $15.69 \%$ \\
SMA & 20 & $39.21 \%$ \\
D1 & 1 & $1.96 \%$ \\
\hline
\end{tabular}


Uji asumsi dilakukan melalui lima tahap, yaitu uji normalitas, uji linieritas, uji multikolinieritas, uji autokorelasi dan uji heteroskedastisitas sebagai prasyarat analisis regresi. Hasil uji normalitas pada pertumbuhan pasca trauma dan dukungan sosial berdistribusi normal $(p>.05)$. Hasil uji linieritas dukungan sosial adalah linier $(p<.05)$. Hasil uji multikolinieritas dukungan sosial tidak ditemukan multikolinieritas ( VIF < 10; tolerance $>.1)$. Hasil uji autokorelasi adalah $d U$ $<D W<4-d U \rightarrow 1.6754<1.703<2.3246$, sehingga tidak ada autokorelasi positif/negatif. Hasil uji heteroskedastisitas adalah signifikan $(p>.05)$, sehingga tidak terjadi heteroskedastisitas.

Hasil uji hipotesis menyatakan bahwa dukungan sosial berperan terhadap pertumbuhan pasca trauma dianalisis dengan regresi sederhana $(F=27.077 ; d f=1$; $\mathrm{SE}=35.16 ; p=.000)$. Hal ini menunjukkan bahwa dukungan sosial berperan secara signifikan terhadap pertumbuhan pasca trauma pada korban difabel akibat gempa sebesar 35.6\%. Besarnya sumbangan efektif dukungan sosial keluarga terhadap pertumbuhan pasca trauma sebesar $11.7 \%(p=.169 ; p<.01)$ dan sumbangan efektif dukungan sosial non-keluarga terhadap pertumbuhan pasca trauma sebesar $24.3 \%(p=.012 ; p>.01)$.

Peranan sumber dukungan sosial dari non-keluarga (teman, masyarakat, tetangga, komunitas, pemerintah) terhadap pertumbuhan pasca trauma lebih besar daripada dukungan sosial yang bersumber dari keluarga. Hal ini didukung dari pernyataan salah satu komunitas korban gempa yang mengalami difabel, yaitu P3Y di wilayah Bantul, bahwa aktivitas yang dilakukan bukan hanya berupa pertemuan rutin yang diadakan selama dua bulan sekali. Perkumpulan yang diadakan oleh P3Y merupakan salah satu wadah dari bentuk dukungan non-keluarga bagi para korban gempa yang mengalami difabel. Selain aktivitas rutin yang dilakukan, komunitas P3Y memiliki agenda lain, seperti kegiatan touring bersama dengan menggunakan motor roda tiga.

\section{DISKUSI}

Hasil analisis menunjukkan bahwa dukungan sosial signifikan berperan terhadap pertumbuhan pasca trauma dengan sumbangan efektif sebesar $36 \%$. Hasil penelitian ini sesuai dengan pernyataan Swickert dan Hittner (2009) bahwa dalam keadaan tertekan, dukungan sosial dapat mengurangi stress sebagai penunjang dalam proses pertumbuhan.

Durak dan Ayvasik (2010) menambahkan bahwa konsep pertumbuhan pasca trauma merupakan perubahan positif pasca krisis yang menunjukkan kontribusi lingkungan, seperti dukungan sosial dengan sumber daya individu, yaitu persepsi terhadap peristiwa dan coping. Hasil 
penelitiannya menemukan bahwa dukungan sosial signifikan berhubungan dengan pertumbuhan pasca trauma sebagai efek dari coping, sedangkan persepsi terhadap peristiwa tidak signifikan berhubungan dengan pertumbuhan pasca trauma.

Gore (1985) menyatakan bahwa sumber daya eksternal berupa dukungan sosial dapat membantu individu mengatasi stresor. Peneitian Schexnaildre (2011) menemukan jika dukungan sosial dengan pertumbuhan pasca trauma memiliki hubungan positif yang signifikan. Schuettler (2011) juga menemukan bahwa dukungan sosial berkorelasi positif dengan pertumbuhan pasca trauma dan berkorelasi negatif dengan PTSD.

Sumber dukungan sosial dalam penelian ini juga dibagi menjadi dua, yaitu dukungan sosial yang bersumber dari keluarga dan non-keluarga. Dukungan sosial yang bersumber dari keluarga terdiri dari pasangan (suami, istri), anak, anggota keluarga lainnya, kerabat, dan saudara. Dukungan sosial yang bersumber dari non-keluarga terdiri dari teman, masyarakat, tetangga, komunitas, dan pemerintah.

Sumber dukungan sosial yang berperan terhadap pertumbuhan pasca trauma dari nonkeluarga memiliki peranan sebesar $24.3 \%$ dan dari keluarga sebesar $11.7 \%$. Temuan dalam penelitian ini sejalan dengan penelitian yang dilakukan oleh Durak dan Ayvasik (2010) bahwa sumber dukungan sosial non-keluarga, seperti teman, sahabat, dan komunitas secara signifikan lebih tinggi berhubungan dengan pertumbuhan pasca trauma. Ketika berkumpul bersama temanteman sesama difabel gempa akan timbul perasaan bahwa mereka tidak sendirian yang memiliki kondisi tersebut. Resiliensi komunitas menjadi salah satu hal yang dapat mengurangi dampak buruk dari sebuah peristiwa berat dalam jangka waktu panjang (Novianty, 2011; Twigg, 2009).

\section{SIMPULAN DAN SARAN}

\section{Simpulan}

Hasil yang diperoleh dalam penelitian ini menunjukkan bahwa dukungan sosial berperan terhadap pertumbuhan pasca trauma pada korban difabel akibat gempa.

\section{Saran Teoretis}

Penelitian selanjutnya diharapkan lebih mempertimbangkan apakah berat ringannya difabel yang diderita subjek juga memiliki peran terhadap pertumbuhan pasca trauma. Selain itu, 
menambah data kualitatif agar proses pertumbuhan pasca trauma subjek dapat digambarkan lebih mendalam, sehingga akan memperkaya referensi yang berkaitan dengan pertumbuhan pasca trauma.

Dukungan yang saat ini masih diperlukan oleh para korban gempa yang mengalami difabel adalah tentang kesehatan mengenai luka yang dialami. Tidak sedikit para korban gempa yang mengalami difabel, khususnya pada tulang belakang (paraplegi dan parilisis) yang memiliki luka tekan (dekubitus). Dalam penelitian ini, korban gempa difabel yang memiliki luka dekubitus parah tidak menjadi subjek penelitian dengan mempertimbangkan kondisi fisik dan etika penelitian.

\section{Saran Praktis}

Hasil penelitian ini menunjukkan bahwa sebanyak 36 orang subjek (70.59\%) memiliki dukungan sosial yang sedang, sementara sebanyak 9 orang subjek (17.65\%) memiliki dukungan sosial yang rendah. Oleh karena itu, diperlukan perhatian dari keluarga, komunitas, pemerintah, dan masyarakat umum. Perhatian dari keluarga dapat diberikan dengan mendampingi korban gempa ketika mengikuti kegiatan-kegiatan. Bagi korban gempa disarankan untuk aktif mengikuti perkumpulan dalam komunitas dengan teman sesama korban gempa yang mengalami difabel dan aktif dalam mengikuti program-program yang diselenggarakan oleh pemerintah dan lembaga nonpemerintah, seperti pelatihan kewirausahaan guna menambah wawasan, pengetahuan, dan keterampilan.

\section{UCAPAN TERIMA KASIH}

Ucapan terima kasih ditujukan kepada Balai Rehabilitasi Terpadu Penyandang Disabilitas Provinsi DIY dan Paguyuban Penyandang Paraplegia Yogyakarta atas dukungan yang telah diberikan untuk pelaksanaan penelitian ini.

\section{REFERENSI}

American Psychiatric Association. 2000. Diagnostic and statistical manual of mental disorders (4th ed.). American Psychiatric Association.

Azwar, S. (2014). Penyusunan skala psikologi. Pustaka Belajar. 
Bensimon, M. (2012). Elaboration on the association between trauma, PTSD, and posttraumatic growth: The role of trait resilience. Personality and Individual Differences, 52, 782-787. doi: 10.1016/j.paid.2012.01.011

Cohen, S., \& Wills, T. (1985). Stress, social support, and the buffering hypothesis. Psychological Bulletin, 98, 310-357.

Djati, T. R. (2010). Penerimaan diri sebagai kunci kesuksesan. Ditemu kembali dari http://sapdajogja.org/wp-content/uploads/2016/02/buletin-difabel-sapda-jogja-edisi-7.pdf

Durak, E. S., \& Ayvasik, H. B. (2010). Factors associated with posttraumatic growth among myocardial infarction patients: Perceived social support, perception of the event and coping. Journal of Clinical Psychology And Medical Settings, 17(2), 150-158. doi: 10.1007/s10880-010-9192-5

Gore, S. (1985). Social support and styles of coping with stress. Dalam S. Cohen \& S. L. Syme (Eds.), Social support and health (hlm. 263-278). Acamedic Press.

Grehenson, G. (2011). Rawan gempa dan tsunami, Bantul perlu perkuat mitigasi. Ditemu kembali dari ugm.ac.id/en/berita/3911rawan.gempa.dan.tsunami.bantul.perlu.perkuat.mitigasi

He, L., Xu, J., \& Wu, Z. (2013). Coping strategies as a mediator of posttraumatic growth among adult survivors of the Wenchuan earthquake. Public Library Of Science (PLOS One), 8(12), 1-7. doi: 10.1371/journal,pone.0084164

Linley, P. A., \& Joseph, S. (2004). Positive change following trauma and adversity: A review. Journal of Traumatic Stress, 17(1), 11-21.

Novianty, A. (2011). Penyesuaian dusun jangka panjang ditinjau dar resiliensi komunitas pasca gempa. Jurnal Psikologi, 38(1), 30-39.

Priyatno, D. (2013). Analisis korelasi, regresi dan multivariate dengan SPSS. Gava Media.

Sawyer, A., Ayers, S., \& Field, A. P. (2010). Posttraumatic growth and adjustment among individuals with cancer or HIV/AIDS: A meta-analysis. Clinical Psychology Review, 30, 436-447.

Schexnaildre, M. A. (2011). Predicting posttraumatic growth: Coping, social support, and posttraumatic stress in children and adolescents after hurricane katrina (Tesis tidak dipublikaskan). Louisiana State University, Louisiana.

Schuettler, D. (2011). Posttraumatic growth: Behavioral, cognitive and demographic predictor (Disertasi). Ditemu kembali dari UMI Database (UMI no. 3506990). 
Sofyan, I. (2010). Motivasi menjadi relawan pada penanganan difabel korban gempa pasca gempa bumi 27 Mei 2006: Studi fenomenologis pada korban gempa yang menjadi relawan (Tesis tidak dipublikasikan). Universitas Gadjah Mada, Indonesia.

Sugiyono. (2012). Metode penelitian kualitatif, kuantitatif, dan R\&D. Alfabeta.

Swickert, R. J., \& Hittner, J. B. (2009). Social support coping mediates the relationship between gender and posttraumatic growth. Journal of Health Psychology, 14, 387. doi: $10.1177 / 1359105308101677$

Tang, C. S. (2006). Positive and negative postdisaster psychological adjustment among adult survivors of the Asian earthquake-tsunami. Journal of Psychosomatic Research, 61, 699705. doi: 10.1016/j.jpsychores.2006.07.014

Tedeschi, R. G., \& Calhoun, L. G. (1996). The posttraumatic growth inventory: Measuring the positive legacy of trauma. Journal of Traumatic Stress, 9(3), 455-471.

Tedeschi, R. G., \& Calhoun, L. G. (2004). Posttraumatic growth: Conceptual foundations and empirical evidence. Psychological Inquiry, 15(1), 1-18.

Twigg, J. (2009). Characteristics of a disaster-resilient community. Ditemu kembali dari https://discovery.ucl.ac.uk/id/eprint/1346086/1/1346086.pdf

Undang-Undang Republik Indonesia. (1997). Undang-Undang Republik Indonesia nomor 4 tahun 1997 tentang penyandang cacat. Ditemu kembali dari http://www.bpkp.go.id/uu/filedownload/2/46/442.bpkp

Urbayatun, S. (2012). Peran dukungan sosial, koping religius-islami dan stress terhadap pertumbuhan pasca trauma (posttraumatic growth) pada penyintas gempa yang mengalami cacat fisik (Disertasi tidak dipublikasikan). Universitas Gadjah Mada, Indonesia.

$\mathrm{Xu}$, J., \& Liao, Q. (2011). Prevalence and predictors of posttraumatic growth among adult survivors one year following 2008 Sinchuan earthquake. Journal of Affective Disorders, 133, 274280. doi: 10.1016/j.jad.2011.03.034

Yu, X., Lau, J. T. F., Zhang, J., Mak, W. W. S., Choi, K. C., Lui, W. W. S., ...Chan, E. Y. Y. (2010). Posttraumatic growth and reduced suicidal ideation among adolescents at month 1 after the Sincuan earthquake. Journal of Affective Disorders, 123, 327-331. doi: 10.10.16/j.jad.2009.09.019 